\title{
Parental Engagement in Children's Online Learning During the Covid-19 Pandemic
}

\author{
Abdul Hafidz ${ }^{1, *}$ Nurhasan ${ }^{1}$ Akh. Muzakki ${ }^{2}$ Syafiul Anam ${ }^{3}$ M. Sholeh ${ }^{4}$ \\ ${ }^{1}$ Faculty of Sport Science, Universitas Negeri Surabaya, Surabaya, Indonesia \\ ${ }^{2}$ Faculty of Social and Political Science, Universitas Islam Negeri Sunan Ampel Surabaya, Surabaya, Indonesia \\ ${ }^{3}$ Faculty of Languages and Arts, Universitas Negeri Surabaya, Indonesia \\ ${ }^{4}$ Faculty of Education, Universitas Negeri Surabaya, Surabaya, Indonesia \\ *Corresponding author. Email: abdulhafidz@unesa.ac.id
}

\begin{abstract}
The emergencies caused by the covid-19 pandemic include many things, one of them is education field which have a new regulation to learn from home. However, not all parents can follow the learning process from home, because not all parents have sufficient time or qualifications to accompany their children. In previous research studies, the topic of parenting learning was limited to research when conditions were normal, not during a pandemic like now. In this study, researchers discussed the importance of parenting education in facing the realities of the learning from home process during the pandemic covid-19. Researchers believe that the argument about family or parents is the basic foundation and important foundation in the learning process of children. The data were collected through questionnaires distributed to parents of primary and secondary school children in four regions of East Java. Results indicated that parents reported quite high involvements in their children online learning during the pandemic. However, there are still some problems that exist regarding how to assist children, and the provision of learning facilities at home.
\end{abstract}

\section{Keywords: Component, Pandemic of Covid-19, Participation of Parents, Learning, Education}

\section{INTRODUCTION}

The parenting program is one of the programs in strengthening family life and the Indonesian community, provides a strengthening in community life, especially early childhood development, parenting methods and communication patterns carried out by most communities. The right approach in family education is expected to provide results in the form of strengthening community accessibility to improve the quality of life through family strengthening. Not only using an economic approach, but also using an educational approach which is expected to be much more capable of shaping the character of Indonesian society in the future. In general, the legal basis for the motherhood program is Law Number 15 of 2015 concerning Amendments to Law Number 20 of 2013 concerning the Protection of Children's Rights. This law is a ratification of the results of the Beijing convention, which seeks to protect the rights of children worldwide from a variety of actions, words, actions or other activities that can hinder children's growth and development.
The emergency caused by the Covid-19 pandemic does not only concern the area of physical resilience in the form of individual and community health, but also extends to other areas, including socio-economic resilience. Education, of course, together with family finances, is one of the important issues behind the emergency in the area of socio-economic resilience in the pandemic era. Following health protocols that must be enforced in a disciplined manner to break the chain of spreading the virus in the community, the government finally adopted a policy that school children must undergo a process that is later known as learning from home. As a consequence, the implementation of formal school education must also experience a shift by including the involvement of parents and children to carry out learning from home which is much higher than in previous times.

As the first experience in the history of formal education in Indonesia, of course the practice of learning from home presents a number of big challenges to parents related to the new task of assisting children in the new type of formal learning process. These challenges relate to mastering the learning material and delivering it to children 
in the mentoring process to self-positioning in acting as a home educator to guarantee the implementation of the learning process from home. Parents who are generally not equipped with the adequacy and skills to educate their children for formal learning begin to experience emotional mental instability. This is especially so when online learning materials cannot be followed convincingly by parents.

Therefore, the readiness and adequacy of the understanding and skills of parents to assist the formal learning process from home is a serious problem in the provision of education in the era of the Covid-19 pandemic. Emergencies that require high parental participation for the continuation of the practice of learning from home by children in the era of the Covid-19 pandemic will not be able to be answered properly except with a level of readiness and adequate understanding and adequate skills regarding the implementation of effective education at home.

The learning process of students or students is not enough at school, in principle the student education process is influenced by three environments, namely: the school environment, the family environment, and the general environment. In the school environment, students study according to a formally established curriculum that takes an average of 7 hours per day. In a family environment, students study accompanied by their families, especially their father or mother. While in the general environment, students will learn to socialize with the surrounding community.

When the Covid-19 Pandemic emergency was implemented, as the community obeyed the law, schools were closed and students had to learn from home, teachers continued to interact with the learning process online. Ironically, with the dismissal of school students, it turns out that most students prefer to be at home. This phenomenon occurs in children, many students or students do not like learning, why? Because they don't feel needed. What needs to be encouraged is how students want to learn, one of which must have dreams or aspirations as motivation. This shows that education in the family environment is very important, especially the participation of the father or mother as a companion to the learning process at home.

The learning process carried out at home can be called home schooling or home education which must be carried out by students because with the Covid-19 pandemic emergency it is a new problem and a new experience especially for most students and their families. In the world of education, the learning process from home can be facilitated by using the e-learning model. The process of learning online from home with a large-scale volume of activity, according to researchers, the urgency of this study is to find out what aspects are learning difficulties for students in carrying out the family-based online learning process (learning from home).

\subsection{Parent-based education}

Regarding previous research that is relevant to this research plan, it can be stated as follows, Novrinda [1] suggests that the role of parents in the education of children in terms of background education in RA Al-Huda, namely the role of parents who graduated from SD, SMP, SMA and Higher Education shows in good categories, namely parents who graduate from SD are in the percentage of $70 \%$, parents are junior high school graduates $72.5 \%$, parents graduate from high school $75 \%$, and parents graduated from higher education $77.5 \%$.

Akhyadi [2] suggests that the motherhood program is an important indicator in increasing family capacity, especially in the micro scale, because currently the development of family quality is expected to be one of the driving forces. Major in increasing competitiveness, amidst the onslaught of foreign cultures and the increasingly massive penetration of foreign cultures in the life of the nation and state

Minister of Education and Culture of the Republic of Indonesia No. 129 of 2014 regulates the existence of homeschooling or home schools. Article 1 Paragraph (4) states that what is mean by home schooling is a conscious and planned process of educational services carried out by parents or family at home or in other places. Article 7 Paragraph (1) states that the curriculum applied in home schools refers to the national curriculum. Finally, Paragraph (3) states that the curriculum used is the formal education curriculum by taking into account the potential and needs of students. Homeschooling is a school that is different from formal schools because homeschooling is done at home or in a certain environment. Homeschooling is a home school [3].

The role of schools and parents in children's education has become an issue that has been questioned a lot lately. Often there are mutual accusations about the party who is most responsible, if something unpleasant happens. Parents blame the school for the educational patterns they do, and 
schools blame parents for the parenting and mentoring that parents have done. There are even parents who think that the important role of children's education lies in the hands of teachers and the environment [4].

Another study even states that family conditions also affect children's achievement at school. The family conditions referred to in the study are feelings of being loved, valued, supported, the level of consistency in the limits of children's behavior, and parental tolerance in encouraging children's independence [5].

Family-based online learning innovation or home education is a learning activity designed for educators, which is new, unlike what is usually done, aimed at facilitating students in building knowledge by involving families in the process of changing behavior for the better. Related to the teaching and learning process in the scope of non-formal education, family-based learning innovation can mean a program created as an effort to find solutions to problems in fostering cooperation between schools and families so that the learning process that takes place at school is also supported and understood by the family.

According to Rachman [6] homeschooling is a school that is held at home. Meanwhile, homeschooling is essentially an alternative school that places children as subjects with an At Home educational approach. With this approach the child feels comfortable. They can learn according to their own preferences and learning styles; anytime and anywhere, like he was in his own house.

According to Komariah [7] homeschooling is an educational service process that is consciously, regularly and directedly carried out by parents / families at home or other places, where the teaching and learning process can take place in a conducive atmosphere with the aim that every potential unique child can develop to its full potential.

According to Sumardiono [8] homeschooling is education that is carried out independently by families, where the materials are selected and adapted to the needs of the child. The greatest characteristic and strength of homeschooling is customized education, which is education that is tailored to the potential of children and the environment around them. In homeschooling the diversity of the child is valued and a child is not required to be uniform and alike.

According to Muhtadi [9], the characteristics of homeschool-based education are as follows:

1. Educational orientation emphasizes the formation of personal character and the development of potential talents and interests of children scientifically and specifically.

2. Learning activities can occur independently, with parents, or with accompanying teachers.

3. Parents play the main role as teacher, motivator, facilitator, dynamist, discussion partner and dialogue partner in determining learning activities and in the process of learning activities.

4. The existence of a teacher (tutor) functions more as a companion and guide for children's interest in the subject he likes.

5. There is flexibility in scheduling learning activities.

6. There is flexibility in setting the number of lesson hours for each subject matter (the discussion will not move to another topic if the child cannot master it and the child is given the opportunity to more broadly determine the topic of discussion for each meeting).

7. The learning approach is more personal and humanist.

8. The learning process is carried out anytime.

9. Give children the opportunity to learn according to their interests, needs, speed, and intelligence.

10. There is no term that children do not go to class, all children can go up to the class according to their respective speeds

The research that has so far only stopped at testing the involvement of parents in the delivery of school education in normal situations, and not emergencies as caused by the recent Covid-19 pandemic. A number of studies [10] [11] [12] [13], shows the trend of the research in question. Indeed, they see the significance of parental involvement in children's school education, but none of their work relates this problem to the context and elements of emergencies caused by the pandemic, especially Covid-19.

The family is an institution that is formed because of marriage ties [14]. In it, living with a husband and wife legally because of marriage.16 The family can be understood from the dimensions of blood relations and social relations. If understood from blood relations, family is a unit bound by blood relations with one another. Based on this dimension, the family can be differentiated into nuclear family and extended family, while from the dimension of social relations, the family is a unit that is bound by interconnection or interaction and influences one 
another, even though there is no blood relationship between them [15]. On the basis of this theory, it can be developed that family relationships are bonds that allow each other to complement each other so that they can become the initial formers of the smallest social system. The family provides the opportunity for its members to develop important parts of their lives to complement each other, and thus can be an added value in building a framework for social life in a broader context.

According to Amini [16], there are 3 main roles that parents can play in developing children's character. First, the obligation to create a warm and peaceful atmosphere. Without peace, it will be difficult for children to learn anything and children will experience obstacles in their mental growth. Tension and fear are bad containers for children's character development. Second, be a positive role model for children because children learn best from what they see, not from what they hear. The character of the parents that is shown through real behavior is the learning material that the child will absorb. Third, educating children means teaching good character and disciplining children to behave in accordance with what they have been taught. The role of parents which is very important like that needs to be nurtured and developed according to their nature so that they can grow and develop according to expectations. Because the child's growth and development process goes hand in hand with time and goes gradually but cannot be repeated. For this reason, parenting education is important if it can be a driving force in fostering community, national and homeland life in the smallest social unit, namely the family.

John W, Santrock [17] suggests that parenting requires a number of interpersonal skills and has large interpersonal demands, but very little formal education on this task. Parenting patterns depend on how a family environment forms the rules (behavior, norms and values) that must be obeyed by family members. This parenting pattern is formed by parents consisting of father and mother to provide education to their children so that they can make an impression on the child and make the child's characteristics and personality. In each family there are different parenting patterns, depending on how the parents view care for their children.

Based on the background, few studies have been done on the parent-based education, let alone in online learning setting in the Indonesian context, Therefore, this study aimed to examine the planning, implementation, results and impact of implementing the parent-based education during the Covid-19 pandemic in The Indonesian province of East Java.

\section{METHOD}

This study employed quantitative approach to address the research questions. The data were collected through questionnaires collected online and offline. There were 246 participants were took part in this study. The participants were parents of primary and secondary school students living in in four regions of East Java Province, Central, North, Mataraman and Madura. The questionnaire was adapted from a number of questionnaires used to assess parents' involvements in education. The data were then analysed using descriptive statistics, that is, mean scores and standard deviation.

\section{RESULT AND DISCUSSION}

\subsection{Activeness of parents towards children's education}

Based on the Table 1, it shows that item 4 "I tell my child to show a good attitude toward online learning" has the highest mean score $(M=4.58)$ which means that most participants prefer their children to behave well. On the other hand, item 15 "I communicate with the teacher about my child's learning activities / achievements" has the lowest mean score $(M=3.10)$ which means the participants have low communication with the teacher about their child learning activities and achievement. 
Table 1. Activeness of parents towards children's education

\begin{tabular}{|c|c|c|}
\hline Item & Mean & SD \\
\hline 1 I ensure my child to study according to their online learning schedule & 4,44 & 0,81 \\
\hline 2. I remind my child to take a rest when they feel tired & 4,26 & 0,90 \\
\hline 3. I have clear expectation about the achievement score of my child in online learning & 4,31 & 0,91 \\
\hline 4. I tell my child to show a good attitude toward online learning & 4,58 & 0,69 \\
\hline 5. I give encouragement to my child when they get poor grades & 4.49 & 0.84 \\
\hline 6. I prepare a supportive home atmosphere so that my child can learn online well & 4.41 & 0.85 \\
\hline 7. I motivate my child to be enthusiastic in doing assignments even though they are not interested & 4.46 & 0.80 \\
\hline 8. I motivate my child to find a right solution in finishing assignment & 4.35 & 0.87 \\
\hline 9. I praise or give gifts to my child for completing online learning assignments well & 3.47 & 1.19 \\
\hline 10. I talked to my son about his studies & 3.88 & 1.03 \\
\hline 11. I make sure my child does his homework & 4.46 & 0.83 \\
\hline 12. I check my child's grades for assignments or exams & 4.08 & 1.05 \\
\hline 13. I limit my child's TV viewing time & 3.95 & 1.08 \\
\hline 14. I give limitation time for using my cellphone / laptop / computer & 4.05 & 1.06 \\
\hline 15. I communicate with the teacher about my child's learning activities / achievements & 3.10 & 1.26 \\
\hline
\end{tabular}

\subsection{Parents' concern for children's education}

The next aspect is Parents' concern for children's education. Table 2 shows that item 2 that is "supporting teachers decisions" has the highest mean score $(\mathrm{M}=4.23)$ which means that parents have higher trust for teacher's decisions. On the other hand, item 4 that is "talk to other students' parents about their child's lessons" has the lowest mean score $(M=3.50)$ which means the communication between students' parents are rarely occurred.

Table 2. Parents' concern for children's education

\begin{tabular}{|l|l|l|}
\hline \multicolumn{1}{|c|}{ Item } & Mean & SD \\
\hline 1.... helping my child with homework & 3.67 & 1.03 \\
\hline 2.... support teacher decisions & 4.23 & 0.81 \\
\hline 3.... explain a difficult task to my child & 3.99 & 0.91 \\
\hline $\begin{array}{l}\text { 4.... talk to other students' parents about } \\
\text { their child's lessons }\end{array}$ & 3.50 & 1.01 \\
\hline 5.... talk to children about online learning & 4.04 & 0.87 \\
\hline
\end{tabular}

\subsection{The ability of parents to provide the best for children}

Afterwards, Table 3 gives information about the ability of parents to provide the best for children, it shows that item 5 "I feel successful in my efforts to help my child" has the higher mean score $(M=4.12)$ which indicates that most of participants has strong believe in their contribution on motivating their children in online learning. On the contrary, item 2 that is ". I feel successful in my efforts to help my child" has the lowest mean score $(M=3.58)$, it indicates that participants still have low self-confidence in their efforts to help their children in online learning. Then, it also indicates that most parents encourage their children in all aspect since the mean score mean scores are not much different. 
Table 3. The ability of parents to provide the best for children

\begin{tabular}{|l|c|c|}
\hline \multicolumn{1}{|c|}{ Item } & Mean & SD \\
\hline $\begin{array}{l}\text { 1. I feel I can help my child well in online } \\
\text { learning }\end{array}$ & 3.67 & 0.95 \\
\hline $\begin{array}{l}\text { 2. I feel successful in my efforts to help my } \\
\text { child }\end{array}$ & 3.58 & 0.95 \\
\hline $\begin{array}{l}\text { 3. I believe I can provide for my child's online } \\
\text { learning needs }\end{array}$ & 4.05 & 0.86 \\
\hline $\begin{array}{l}\text { 4. I believe I can communicate well with my } \\
\text { child about online learning }\end{array}$ & 3.95 & 0.86 \\
\hline $\begin{array}{l}\text { 5. I believe I can motivate my child to learn } \\
\text { online }\end{array}$ & 4.12 & 0.84 \\
\hline
\end{tabular}

\subsection{Parents' knowledge of what is good for children's education}

As shown in Table 4, item 5 that is "I have sufficient knowledge about the subject matter to my child" has the highest mean score $(M=4.08)$ which means that most of participants or parents are aware how to provide their children supporting place for learning. On the other hand, item 2 that is "I have sufficient knowledge about the subject matter to my child" has the lowest mean score $(M=3.46)$, it implies that the knowledge of the participants about their children subject matter is low.

Table 4. Parents' knowledge of what is good for children's education

\begin{tabular}{|l|l|l|}
\hline \multicolumn{1}{|c|}{ Item } & Mean & SD \\
\hline $\begin{array}{l}\text { 1. I know how to communicate effectively with } \\
\text { my child about daily online learning }\end{array}$ & 3.82 & 0.85 \\
\hline $\begin{array}{l}\text { 2. I have sufficient knowledge about the subject } \\
\text { matter to my child }\end{array}$ & 3.46 & 0.98 \\
\hline $\begin{array}{l}\text { 3. I know how to communicate effectively with } \\
\text { my child's teacher }\end{array}$ & 3.60 & 0.96 \\
\hline $\begin{array}{l}\text { 4. I know how to assist children in doing } \\
\text { homework }\end{array}$ & 3.90 & 0.90 \\
\hline $\begin{array}{l}\text { 5. I know how to help children learn by providing } \\
\text { a supportive place }\end{array}$ & 4.08 & 0.82 \\
\hline
\end{tabular}

\subsection{Encouragement of parents towards children's education problems}

Table 5 demonstrates that item 5 that is "I encourage my child to develop interest in learning" has the highest mean score $(M=4.43)$ which indicates that the participants or parents have a strong encouragement to their children in increasing their interest in learning. Interestingly enough, item 4 that is "I encourage my child to find effective ways to solve problems in learning" has the lowest mean score $(M=4.26)$ which means that the participants has higher encouragement on increasing interest but they have low encouragement in assisting their children for finding the effective ways to solve problem in learning.

Table 5. Encouragement of parents towards children's education problems

\begin{tabular}{|l|l|l|}
\hline \multicolumn{1}{|c|}{ Item } & Mean & SD \\
\hline $\begin{array}{l}\text { 1. I encourage my child when he is lazy } \\
\text { to do assignments }\end{array}$ & 4.33 & 0.83 \\
\hline $\begin{array}{l}\text { 2. I encourage my child to seek } \\
\text { information about lessons }\end{array}$ & 4.28 & 0.79 \\
\hline $\begin{array}{l}\text { 3. I encourage my child to do well in } \\
\text { school }\end{array}$ & 4.31 & 0.82 \\
\hline $\begin{array}{l}\text { 4. I encourage my child to find effective } \\
\text { ways to solve problems in learning }\end{array}$ & 4.26 & 0.77 \\
\hline $\begin{array}{l}\text { 5. I encourage my child to develop } \\
\text { interest in learning }\end{array}$ & 4.43 & 0.74 \\
\hline
\end{tabular}

From the results of the table above, it can be concluded that parents have high awareness to encourage their children to behave well during online learning. In other words, parents have crucial roles to children's characters. This results is in line with Amini's [16] and Muhtadi's [9] statement, they stated that parents play important roles in developing children's character. For this reason, positive obligation from parents will influence children's education. Also, in the aspect of parents' concern for children's education, parents support the teacher's decision. It means that parents obey what the teacher decide about children's education. It is supported by Muhtadi [9] statement where the existence of teacher is to guide children's interest in the subject he likes. Furthermore, the others aspects show that participants has strong believe in their contribution on motivating their children in online learning, they recognize in how to provide their children supporting place for 
learning, and participants or parents have a strong encouragement to their children in increasing their interest in learning. Those results are supported by Franklin et. al. [5] that family conditions also affect children's indicate that parents have positive attitude toward their children's education during pandemic.

Based on the results it can be concluded that parents support their children learning process during pandemic by providing the best preparation for children and increasing children motivation to study better.

\section{CONCLUSION}

The pattern of parenting learning that occurred in the pandemic showed some positive results, where parents began to apply it. However, there are still some problems that exist regarding how to assist children, and the provision of learning facilities at home. For the recommendation, for education policy makers in East Java to provide socialization and assistance to implement parental education, for further researchers to carry out development research, by developing an applicable learning pattern.

\section{REFERENCES}

[1] Y. Novrinda, Nina Kurniah, "Peran Orangtua Dalam Pendidikan Anak Usia Dini Ditinjau Dari Latar Belakang Pendidikan," Potensia, vol. 2, no. 1, 2017.

[2] A. S. Akhyadi and D. Mulyono, "Program Parenting Dalam Meningkatkan Kualitas Pendidikan Keluarga," Abdimas Siliwangi, vol. 1, no. 1, p. 1, 2019.

[3] D. Y. Sugiarti, "Mengenal Homeschooling Sebagai Lembaga Pendidikan Alternatif," Edukasi, vol. 1, no. 2, pp. 13-22, 2009.

[4] Sugihandari, "Pentingnya Partisipasi Keluarga dalam Pendidikan Anak", Kompas., 2015.

[5] W. Franklin, L. Steinberg, B. B. Brown, and S. Dornbusch, "Beyond the Classroom: Why School Reform Has Failed and What Parents Can Do.," J. Negro Educ., vol. 65, no. 3, p. 396, 1996.
[6] A. Rachman, "Homeschooling rumah kelasku, dunia sekolahku", PT. Kompas Media Nusantara., Jakarta, 2007.

[7] Y. Komariah, "Homeschooling tren baru sekolah alternatif", Sakura Publising., Jakarta, 2007.

[8] Sumardiono, "Apa Itu Homeschooling", Panda Media, Jakarta selatan, 2014.

[9] Muhtadi, Ali. 2011. "Pendidikan dan Pembelajaran di Sekolah Rumah (Home Schooling)", 2011. [Online], Available: staff.uny.- ac.id.

[10] W. S. Grolnick and M. L. Slowiaczek, "Parents' Involvement in Children's Schooling: A Multidimensional Conceptualization and Motivational Model," Child Dev., vol. 65, no. 1, pp. 237-252, 1994.

[11] Yun Mo \& Kusum Singh. Parents Relationships and Involvement: Effects on Students' School Engagement and Performance Pages 1-11 | Published online: 25 Aug 2015

[12] Y. De Gaetano, "The role of culture in engaging Latino parents' involvement in school," Urban Education, vol. 42, no. 2. pp. 145-162, 2007.

[13] S. M. McHale, L. Shanahan, K. A. Updegraff, A. C. Crouter, and A. Booth, "Developmental and individual differences in girls' sex-typed activities in middle childhood and adolescence," Child Dev., vol. 75, no. 5, pp. 1575-1593, 2004.

[14] B. S. Djamarah, "Pola Komunikasi Orang Tua \& Anak Dalam keluarga". Reneka Cipta., Jakarta, 2004.

[15] M. Shochib, "Pola Asuh Orang Tua Dalam Membantu Mengembangkan Disiplin Diri", Rineka Cipta., Jakarta, 1998.

[16] M. Amini, "Pengasuhan Ayah Ibu Yang Patut, Kunci Sukses Mengembangkan Karakter Anak", dalam Arismantoro (Peny.), Tinjauan Berbagai Aspek Character Building, Tiara Wacana., Yogyakarta, 2008.

[17] J. H. Santrock, "Perkembangan Anak", Erlangga, Jakarta, 2007. 